\title{
Factors Affected Low Coverage of Exclusive Breastfeeding in Cilacap Tengah, Central Java, Indonesia
}

\author{
Pemi Sunarsih Ruhyana'), Pawito's), Uki Retno Budhiastuti3) \\ 1)Academy of Midwifery Graha Mandiri, Cilacap, Central Java \\ 2)Faculty of Social and Political Sciences, Universitas Sebelas Maret \\ 3)Department of Obstetrics and Ginecology, dr. Moewardi Hospital, Surakarta
}

\begin{abstract}
Background: Human resources (HR) quality is a requirement of absolute attainment of development in all fields. Nutritional status of being one of the very important factors in the quality of human resources is mainly associated with intelligence, productivity and creativity. To achieve an optimum between flower growing by giving breast milk to infants from birth in the early minutes of life until the age of 6 months exclusive breast milk given without other food. This study was aimed to determine the cause of the low coverage of breast milk exclusively and the factors that affected it.

Subject and Method: This was a case study with qualitative design, was carried out in Cilacap, Central Java, from July to August 2016. A total sample of parents with infants aged 7-24 months of age, the mother/mother-in-law and health workers. The data was collected by interviews, observation and documents, and analyzedwith data presentation, data reduction, and the withdrawl of the conclusion.

Results: Pre-disposing Factors good motivation, attitudes, education and employment of the informant was indeed affect Exclusive breast feeding in the process. Enabling Factors are readily available and easily accessible due to the support of the party giver services though in terms of infrastructure there are still shortcomings in various things. While Reinforcing factors demonstrates the role of health workers and the people closest to either mother or mother-in-law strongly affect the behavior of the mother in giving breast feedingexclusively. Restricting factors namely wrong beliefs about the incessant promotion of baby food, infant formula and health problems in the mother and the baby. In addition, the existence of the recording and reporting of less fit so that it affects the actual coverage figures in society.

Conclusion: the cause of the low coverage of exclusive breast feeding include knowledge of mother/mother-in-law limited about breast milk exclusively, the role of health workers that is not optimal, the existence of a mistaken beliefs and culture in the community about exclusive breastfeeding, recording and reporting factors that still need to be addressed so that exclusive breastfeeding data in accordance with the conditions in the community.
\end{abstract}

Keywords: exclusive breast feeding, coverage

Correspondence:

Pemi Sunarsih Ruhyana. Midwifery Academic Graha Mandiri Cilacap, Jl. Dr. Soetomo No. 4B Cilacap. Email: pemisunarsihruhyana@gmail.com.

\section{BACKGROUND}

For the sake of the realization of national development, the development needs to be carried out thoroughly in all aspects of the life of the nation. Quality human resources is an absolute requirement for the realization of development in all fields and aspects. Nutritional status is one of the factors that play an important role in the quality of human resources, especially those related to intelligence, productivity and creativity. To achieve the optimal growth and development between giving breast milk to babies from birth in the early 
minutes of life until the age of 6 months, breast milk is given exclusively without other food, then after 6 months breastfeeding is still provided accompanied by complementary food adjusted for the age.

Exclusive breastfeeding for 6 months has been proven good for health one of them is that it can reduce the level of morbidity and mortality of infants caused by gastrointestinal infections (Kramer and Michael, 2003), and improve cognitive development (Krammer and Michael, 2008). One of the benefits of exclusive breastfeeding for the mother is that it can reduce the risk of postpartum bleeding.

Global Strategy for Infant and Young Child Feeding recommends only breastfeeding or exclusive breastfeeding from birth to 6 months old baby (WHO/ UNICEF, 2009). UNICEF states that 30,000 infant deaths in Indonesia and 10 million under-five deaths in the world each year can be prevented by exclusive breastfeeding for 6 months after birth without having to provide additional food and drinks to the baby. UNICEF said that the latest scientific evidence in the pediatric journal in 2006 revealed that data on formula-fed infants had the possibility to die in the first month of birth, with a 25 -fold higher chance of being exclusively breastfed by babies.

In Indonesia, research and observations carried out in various regions clearly show the tendency of increasing numbers of mothers who do not breastfeed their babies. Based on the 2002 Indonesian Demographic Health Survey (IDHS), only 3.7\% of babies received breast milk on the first day. While breastfeeding for infants less than 2 months old is $64 \%$, between $2-3$ months is $45.5 \%$, between $4-5$ months is $13.9 \%$ and between 6-7 months is $7.8 \%$. Babies under 2 months of age, $13 \%$ of whom have been given milk and one in three infants aged 23 months have been given additional food.
Infants under 6 months of age use formula milk at $76.6 \%$ in breastfed babies and $18.1 \%$ in breastfed babies (Briawan, 2004).

Similarly, the results of the Riskesdas data collection in 2013 showed that the coverage of the exclusive breastfeeding national average was only around 30.2\%. While the coverage rate for exclusive breastfeeding in Central Java in 2013 was $58.4 \%$ (Ministry of Health Republic of Indonesia, 2013). Cilacap Regency has 44 health centers with their respective working areas and there are still areas where the coverage of exclusive breastfeeding is still low, namely public health centerin Cilacap Tengah I which is $12.19 \%$ of the total number of male and female babies as many as 747 babies. This amount includes the least coverage of exclusive breastfeeding for infants aged o-6 months compared to all health centers in Cilacap Regency (Cilacap District Health Office, 2014).

The formulation of the problem of this research is "how is the practice of exclusive breastfeeding, predisposising factors, enabling factors, reinforcing factors and inhibiting factors in exclusive breastfeeding in the work area of the Cilacap Tengah Health Center I, Cilacap Tengah District, Cilacap Regency?" This study aims to analyze the causes of the low coverage of exclusive breastfeeding in the working area ofCilacap Tengah Health Center I, Cilacap Tengah District, Cilacap Regency. Meanwhile, the specific objective is to explore information about exclusive breastfeeding practices, predisposising factors in exclusive breastfeeding, enabling factors, reinforcing factors, inhibiting factors of exclusive breastfeeding.

\section{SUBJECTS AND METHOD}

This was a qualitative study carried out in Cilacap Tengah Health Center I, Cilacap Tengah District, Cilacap, Central Java, from 
July to August 2016. In-depth interviews involved 19 informants consisting of mothers of infants aged 7-24 months who gave exclusive breastfeeding, mothers who gave exclusive breastfeeding, mothers of infants aged 7-24 months who did not provide exclusive breastfeeding, Head of Central Cilacap Health Center I, Nutrition Officer, Health Promotion Officer, Midwife Coordinator, Sidanegara District Midwife, Mount Simping District Midwife and Lomanis District Midwife. While Focus Group Discussion (FGD) was held on 16 September 2016 at Cilacap Tengah I public health center with informants of toddlers aged 7-24 months giving exclusive breastfeeding and mothers of infants aged 7-24 months who did not provide exclusive breastfeeding.

This study uses purposive sampling sampling technique with a number of samples of 19 people with criteria that match the topic of this study. The data were taken in the form of primary data and secondary data. The primary data were taken from from District Health Office Profile and the secondary data were carried out by conducting in-depth interviews and Focus Group Discussion (FGD). The validity test uses a source triangulation. The data analysis in this study includes data collection, data reduction, presentation, and drawing conclusions.

\section{RESULTS}

Data from informants in this study were obtained by conducting Focus Group Discussions and in-depth interviews with mothers who had children aged 7-24 months as the main informants. For data validity, triangulation of sources was carried out, namely information from mothers or mothers-in-law from mothers of toddlers, midwives, nutrition workers, health promotion officer and head of public health center. The characteristics of informants are presented in Table 1.

Especially with regard to informant knowledge about exclusive breastfeeding, it is one of the basis for someone to act in exclusive or not breastfeeding. Almost most of them know about breast milk, but not all mothers can give exclusive breastfeeding to their babies even though they know about exclusive breastfeeding. The choice of the mother who gave exclusive breastfeeding was from the informant $\mathrm{H}$ and informant I as follows:

"ASI Eksklusif yaitu memberikan ASI kepada bayi tanpa tambahan makanan kecuali obat-obatan. ASI yaitu air susu ibu yang diberikan kepada bayi. Kolostrum yaitu ASI yang berwarna kuning." $(H)$

As for the mother / mother-in-law informants, most of them said they did not understand breastfeeding so that it affected the parenting style in feeding other than ASI. Most of them, especially those with limited knowledge, give advice for giving food other than breast milk to babies. In relation to exclusive breastfeeding expenditure, all maternal informants who gave exclusive breastfeeding said that their breast milk had come out before giving birth. Physiologically breast milk comes out on the third day after giving birth. However, some informants have experienced breastfeeding not come out after giving birth. It does not affect the mother's behavior in giving exclusive breastfeeding. It is like the statement given by the mother informant who gave exclusive breastfeeding presented below:

"ASI saya dulu keluar pas sebelum bersalin sudah keluar sedikit.”(H)

"selagi saya masih hamil ASI saya sudah keluar." (I). 
Table 1. Informant Characteristics

\begin{tabular}{|c|c|c|c|c|c|c|c|}
\hline No & Informant & Age & Occupation & Education & $\begin{array}{l}\text { Number } \\
\text { of child }\end{array}$ & $\begin{array}{c}\text { The } \\
\text { youngest } \\
\text { child's age }\end{array}$ & Method \\
\hline \multicolumn{8}{|c|}{ Characteristics of Mother Informants Who Don Not do Exclusive Breastfeeding } \\
\hline 1 & Informant A & $41 \mathrm{y} .0$ & Housewife & JHS & 1 & 13 months & FGD \\
\hline 2 & Informant B & 35 y.o & Labor & SHS & 2 & 8 months & FGD \\
\hline 3 & Informant $\mathrm{C}$ & 29 y.o & Housewife & Bachelor & 1 & 10 months & FGD \\
\hline 4 & Informant D & 30 y.o & Housewife & SHS & 2 & 8 months & FGD \\
\hline \multicolumn{8}{|c|}{ The characteristics of Informants (Mother Who Do not Give Exclusive Breastfeeding) } \\
\hline 5 & Informant $\mathrm{E}$ & 69 y.o & Housewife & PS & - & - & WM \\
\hline 6 & Informant F & 56 y.o & Housewife & PS & - & - & WM \\
\hline 7 & Informant G & 70 y.o & Housewife & PS & - & - & WM \\
\hline \multicolumn{8}{|c|}{ Characteristics of Mother Who Providing Exclusive Breastfeeding } \\
\hline 8 & Informant $\mathrm{H}$ & 30 y.o & Housewife & SHS & 1 & $1 \mathrm{y} .0$ & WM \\
\hline 9 & Informant I & 28 y.o & Civil servant & Bachelor & 1 & 1.3 y.o & WM \\
\hline \multicolumn{8}{|c|}{$\begin{array}{l}\text { Characteristics of Informant Mother / In-law from Mother of Toddlers who Provide } \\
\text { Exclusive ASI }\end{array}$} \\
\hline 10. & Informant $\mathrm{J}$ & 66 y.o & Housewife & JHS & - & - & WM \\
\hline 11. & Informant $\mathrm{K}$ & 72 y.o & Housewife & PS & - & - & WM \\
\hline 12. & Informant L & 60 y.o & Housewife & PS & - & - & WM \\
\hline \multicolumn{8}{|c|}{ Characteristics of Health Personnel of Cilacap Tengah I health center } \\
\hline 13. & Officer M & $47 \mathrm{y} .0$ & The head & $\begin{array}{c}\text { Master degree- } \\
\text { Management }\end{array}$ & - & - & WM \\
\hline 14. & Officer $\mathrm{N}$ & 28 y.o & Nutritionist & D3-Nutrition & - & - & WM \\
\hline 15. & Officer O & 39 y.o & $\begin{array}{l}\text { Promotion } \\
\text { officer }\end{array}$ & $\begin{array}{l}\text { Bachelor- } \\
\text { nursery }\end{array}$ & - & - & WM \\
\hline 16. & Officer P & 38 y.o & $\begin{array}{l}\text { Midwife } \\
\text { coordinator } \\
\text { Sidanegara }\end{array}$ & D3-midwifery & - & - & WM \\
\hline 17. & Officer Q & $27 \mathrm{y} .0$ & $\begin{array}{l}\text { District } \\
\text { Midwife }\end{array}$ & D3-Midwifery & - & - & WM \\
\hline 18. & Officer F & 35 y.o & $\begin{array}{l}\text { GunungSimpi } \\
\text { ngDistrict } \\
\text { Midwife }\end{array}$ & D3-Midwifery & - & - & WM \\
\hline 19. & Officer G & 28 y.o & $\begin{array}{l}\text { LomanisDistri } \\
\text { ct Midwife }\end{array}$ & D3-Midwifery & - & - & WM \\
\hline
\end{tabular}

Likewise, there are many obstacles that make mothers unable to give breast milk exclusively to their babies. One of them is the ASI production factor, some of the informants were less in volume or related to the condition of their sick babies so the informants were forced to provide food other than Exclusive ASI when the baby was less than 6 months old. The statement was conveyed by informant B as a mother who did not give exclusive breastfeeding:

"Saya gak bisa ASI Eksklusif karena setelah saya bekerja, ASI saya jadi makin berkurang. Ditambah lagi di pabrik gak bias memerah ASI jadi kalau mau neteki ya harus pulang kerumah. ASI yang diperas keluarnya cuma sedikit.” (B).

"I know about breast milk from relatives, Internet, midwives, and obstetricians" $(\mathrm{H})$

"Informasi tentang ASI dari ibu, teman, internet, bidan, dokter." (C).

"I got the information about breast milk from mother, friends, Internet, midwives, and doctor" (C).

This was in contrast to the statements of informants who said that they rarely participated in activities at the health center. While in fact, there were still many 
mothers with toddlers who did not register to the data of exclusive or non-exclusive breastfeeding. Therefore, it can be stated that there was still a lot of coverage of exclusive breastfeeding that was not recorded. It can be seen from the statement of mother who did not provide exclusive breastfeeding as follows:

"Informasi yang saya dapatkan sangat bermanfaat tetapi saya jarang ikut. Saya lebih sering ke dokter kandungan.”(D).

"The information that I got is very beneficial, but I did not join the activity a lot. I often go to obstetricians" (D).

In relation to the provision of information about exclusive breastfeeding, the activities of officers during health service were very important because there were more counseling activities on exclusive breastfeeding in the health services activities. Most informants stated that officers or cadres at the health services had their own activities which in accordance with their duties and functions. However, some informants said that those who often did their work in health services were the cadres instead of the midwives. When the participants were asked about the topic of the counselling, they stated that there were many topics regarding the counseling, and one of them was about exclusive breastfeeding as the following statements:

"Kalau pas posyandu biasanya diisi sama kader. Bu bidannya saat-saat tertentu aja dating ke posyandu. Kalau kelas ibu hamil biasanya di puskesmas tapi saya jarang ikut karena sudah periksa di bidan." (A).

"In the health services, the cadre usually provide the services. The midwives only came in a certain time. The pregnancy class is usually held at health center, but I rarely participated because I have visited the midwife." (A).
"Saat posyandu kegiatanya ada nimbang, ngasih vitamin, penyuluhan oleh kader kadang juga oleh bidan." (D).

"In a health services, the activities are weighing, giving vitamins, and counseling by cadres and midwives." (D).

In contrary to the statement above, there were informants who said that they rarely participate in activities organized by the health center as stated below:

"Kalau posyandu saya jarang ikut karena biasanya pas posyandu pas saya kerja jadi sering tidak ikut. Kelas ibu hamil saya sering ikut, biasanya diisi oleh bidannya." (B).

"I rarely participate in the health service activities because I am working and therefore, I cannot join the activity. I often join pregnancy class, and it usually lead by the midwives." (B).

"Saya jarang mengikuti posyandudan kelas ibu hamil karena selama ini saya periksa kehamilan ke dokter." (C).

"I rarely participate in health services and pregnancy class because I have checked my pregnancy to the doctor." (C).

Regarding the statements of the informants about the exclusive breastfeeding program, some informants stated that there was a program but it still very low as described below:

"Program ASI Eksklusif cakupannya sudah meningkat dan mencapai target pada tahun 2015. Pada tahun 2014 memang cakupannya sekitar $12.18 \%$ termasuk cakupan yang sangat rendah. Peningkatannya memang agak drastic dari tahun sebelumnya karena ada semacam kesepakatan mengenai cakupan ASI Eksklusif dari DKK agar cakupannyameningkat." $(O)$.

"The exclusive breastfeeding program has increased in term of coverage and reached its target in 2015. In 2014, the coverage was around $12.18 \%$ and it was a 
very low coverage. The increase was rather drastic from the previous year because there was a kind of agreement regarding the scope of Exclusive Breastfeeding from the DKK so that the scope would increase." (O-Interview on the 12th of August, 2016)

This was in line with the statement of the Head of the health center regarding the exclusive breastfeeding as stated in the following paragraph:

"Namun cakupan pemberian ASI Eksklusif pada tahun 2015 sudah mengalami peningkatan dibanding tahun 2014 kemarin yang sempat jauh dari target." $(N)$.

"However, the coverage of Exclusive Breastfeeding in 2015 has increased compared to 2014, which was far from the target." (N).

Related to the exclusive breastfeeding program which was already available and known by various parties, however, in its implementation, there were some weaknesses in various factors that have resulted in the lack of target in program's coverage. This was caused by various sectors, it was not only from the community but also from other sectors such as cultural influences, the involvement of people around, and others.

Data recording and reporting also came from the help of cadres who were directly in contact with the situation in the field. Therefore, in the recording and reporting system, there were some weaknesses as revealed by the Head of the health center as follow:

"Sistem pencatatan dan pelaporan dilakukan oleh petugas gizi. Sebagai kepala puskesmas, saya juga menyadari kelemahan dalam system pencatatan dan pelaporan, misalkan jika terjadi recall kader dimana kemampuan kader dalam menggali informasi tentang ASI Eksklusif kepada ibu yang meliputi cara menanya- kan kepada ibu atau orang yang membawa bayi ke posyandu, cara melaporkan ke petugas puskesmas dan sebagainya. Masih banyak kelemahan dalam sistem pencatatan dan pelaporan salah satunya tentang ASI Eksklusif." (N).

"The recording and reporting system was carried out by nutrition personnels. As the head of the health center, I am also aware of the weaknesses in the recording and reporting system, for example there is a cadre recall, it is about the cadre's ability to ask the information about exclusive breastfeeding to the mothers includes ways to ask the mother or the person who brought the baby to the health services, how to report to the health center staff, and the like. There were still many weaknesses in the recording and reporting system, one of them was about exclusive breastfeeding." (N).

In this regard, the system of recording and reporting of exclusive breastfeeding at the Central Cilacap Health Center I, although the coverage was very low, it was still reported to the District Health Office (DKK) Cilacap. However, due to the low coverage of exclusive breastfeeding in some regions, an agreement was made that it should not have been done because it did not describe the actual data as stated below:

"Sistem pencatatan danpelaporan tentang ASI Eksklusif diserahkan kepada petugas gizi, yang dalam hal ini adalah saya sendiri. Dalam system tersebut masih banyak sekali kelemahan diantaranya pelaporan dilaksanakan oleh kader kemudian diserahkan kepada petugas gizi dan juga adanya kesepakatan dari Dinas Kesehatan Kabupaten tentang system pencatatan dan pelaporan yaitu ibu yang tidak terdata atau tidak dating maka tidak dihitung dalam penghitungan cakupan, apabila ada bayi usia $0-7$ hari diberi susu formula sementara kemudian dilanjutkan 
Journal of Health Policy and Management (2016), 1(1): 20-28

https://doi.org/thejhpm.2016.01.01.04

dengan ASI lagi maka masih masuk dalam hitungan ASI Eksklusif meskipun secara teori hal tersebut menggugurkan ASI Eksklusif. Hal tersebut dilakukan untuk meningkatkan cakupan pemberian ASI Eksklusif maka dari itu pada tahun 2015 cakupannya meningkat menjadi $80.2 \%$ dari semula tahun 2014 sebesar 12.18\%." (O).

"The system of recording and reporting about exclusive breastfeeding was handed over to nutrition workers, which in this case was myself."

In this system, there are still many weaknesses, including reporting carried out by cadres and then handed over to nutrition workers and also an agreement from the District Health Office regarding the recording and reporting system, such as mothers who are not registered or not coming, then it is not counted in the calculation of coverage, if there is a baby aged $0-7$ days who get temporary formula milk and then continued with breast milk, it is still included in the exclusive breastfeeding even though in the theory it is not included.

"This was done to increase the coverage of exclusive breastfeeding, therefore, in 2015 its coverage increased to $80.2 \%$ while in 2014 it was $12.18 \%$." (O).

Related to the causes of the low coverage of exclusive breastfeeding in the working area of the Central Cilacap Health Center I, many factors must be taken into account so that it did not continue continuously, one of them was the factor of recording and reporting. By the fact that the data obtained by health personnels was data collected by cadres who still have many obstacles and weakness such as there was an uncovered mother's data, filling the data was sometimes not valid and there was an agreement from the District Health Office about calculating the coverage number.
It mean that the existing data was less valid and did not show the actual facts in the community. This definitely would affect the government budget, policies on exclusive breastfeeding, and subsequent programs from the government and could cause the policies and programs to be not right on the target, it would also make the program to be ineffective and inefficient and not in accordance with the program or policy objectives.

DISCUSSIONS
According to Skinner (1983) in Syah (2008), theories about behavior were caused by internal and external factors. Internal factors of the maternal behaviour who did not provide exclusive breastfeeding were quite well, and it was proven by the knowledge of informants about the meaning of breast milk, exclusive breastfeeding, and colostrum. Some informants can answer correctly while others cannot answer correctly from that understanding. However, this was different from the informants who provided exclusive breastfeeding. Most informants can answer correctly about the meaning of breast milk, exclusive breastfeeding, and colostrum. Whereas in theory, external factors can be physical, non-physical, social, cultural, and economic. In this case, the closest people beside the subject informants also greatly affected the maternal behavior in giving exclusive breastfeeding. In addition, external factors were the factors that have a great role in the form of human behavior because it was influenced by social and cultural factors in which a person lived.

In addition, there were other factors that affected the scope of exclusive breastfeeding, namely the system of recording and reporting related to the data of mothers who provide/did not provide exclusive breastfeeding which needed to be corrected 
further. This can be seen from the statement of health personnels who stated that in order to increase the coverage of exclusive breastfeeding, an agreement was made between the nutrition staff and the District Health Office regarding the calculation of coverage where mothers were not recorded by cadres or health personnels so that the amount was not included in the calculation of coverage.This lead to errors in the calculation of coverage intentionally and also the data was not valid to describe the situation in the community so that it was very influential on the next policy which related to exclusive breastfeeding.

Health problems were also the inhibiting factor in exclusive breastfeeding. One informant stated that she could not give exclusive breastfeeding because her baby had diarrhea problems and was forced to provide food other than breast milk at the age of less than 6 months. And the environmental factors where mothers live also affected the maternal behavior in providing exclusive breastfeeding. Mothers who lived in urban areas and who provide/ did not provide exclusive breastfeeding, there was a "prestige" factor in the pattern of feeding the baby. This was shown by several opinions from informants stating that it was a prestige when the mothers can provide formula milk with high brands or expensive prices to their babies than giving exclusive breastfeeding which was more economical and cheaper and easier to digest. Therefore, socio-cultural factors also influenced the maternal behavior in giving exclusive breastfeeding.

However, it was different from one of the predisposising factors that affect breastfeeding, namely the motivation of the closest person. It was different from the theory which was shown by the statement of the informant who revealed that her mother-in-law did not support exclusive breastfeeding but the informant still had the willingness and confidence to be able to give exclusive breastfeeding to her baby even though the production of breast milk was less and it did not fulfill the baby's needs. Therefore, external motivation has insignificant effect on determining a person's behavior in making decisions.

The demographic character of a residential environment that was theoretically closer to urban and has higher education, then the awareness of health and affordability of health facilities was also higher. However, this was not appropriate, especially in the implementation of exclusive breastfeeding due to the prestige factor that made the formula milk to be more expensive, so the parents tend to be more proud of it. This was revealed by the health informants of Central Cilacap Health Center I regarding the lifestyle of the community in their working area.

\begin{tabular}{c}
\hline REFERENCES \\
\hline Baskoro A (2008). ASI Panduan Praktis Ibu \\
Menyusui. Yogyakarta: Banyu Media. \\
Aritonang, Citra BR (2011). Hubungan Ka- \\
rakteristik, Pengetahuan, Sikap dan \\
Perilaku Keluarga dengan Perilaku \\
Pemberian ASI Eksklusif di Puskes- \\
mas Bandar Haluan Kabupaten Sima- \\
lungun Prov Sumatra Utara. FKM UI. \\
As'ad M (2005). Psikologi Industri Seri \\
Ilmu Sumber Daya Manusia. Yogya- \\
karta: Liberty. \\
Briawan D (2004). Pengaruh Susu Formula \\
terhadap Penggunaan Air Susu Ibu. \\
Disertasi:Bogor. Program Doktor Se- \\
kolah Pasca Sarjana IPB. \\
Departemen Kesehatan RI (20o7). Pedo- \\
man Pendampingan Keluarga Menuju \\
Kadarzi: Jakarta. \\
(2001). Buku Panduan Manajemen \\
Laktasi, Dit. Gizi Masyarakat. Jakarta.
\end{tabular}


Journal of Health Policy and Management (2016), 1(1): 20-28

https://doi.org/thejhpm.2016.01.01.04

(2009). Pedoman Pemantauan Wilayah Setempat Kesehatan Ibu dan Anak (PWS-KIA). Jakarta.

(2004a). Kepmenkes RI No.45o/ MENKES/IV/2004 tentang Pemberian Air SusuIbu (ASI) secara Eksklusif pada Bayi Indonesia.Jakarta.

(2004b). Kebijakan Departemen

Kesehatan tentang Peningkatan Pemberian Air Susu Ibu (ASI) Pekerja Wanita. Jakarta.

(2005). Manajemen Laktasi: Buku Panduan bagi Bidan dan Petugas Kesehatan di Puskesmas, Dit. Gizi Masyarakat. Jakarta.

Denzin N, Lincoln YS (2000). Handbook of Qualitative Research. London: Sage Publications.

Green LW, Kreuter (1991). Health Promotion Planning an Educational and Environmental Approach. 2nd Ed, Mayfield Publishing Company, London: 142-177.

Kementrian Kesehatan RI (2010). Rencana Aksi Pembinaan Gizi Masyarakat.

(2010). Surat Edaran Penguatan Pelaksanaan Sepuluh Langkah Menuju Keberhasilan Menyusui No. BM/E/Menkes/1407/IX/2010.

Krammer, Michael S (2008).Breast Feeding and Child Cognitive Development. Arch Gen Psychiatry. 65(5): 5785584 .

Lawrence RA (1994). Breastfeeding: A Guide for The Medical Profession, 4th Ed, Mosby, Missouri. Nutrition and Health Surveillance System, 2002, Breastfeeding and Complementary Feeding Practices in Indonesia, Nutrition and Health Surveillance System Annual Report 2002. Helen Keller Worldwide. Jakarta.

Moleong LJ (2006).Metode Penelitian Kualitatif. Bandung: PT. Remaja Rosdakarya.
Nuryanto (2002). Hubungan Faktor Ibu, Faktor Pelayanan Kesehatan dan Pemberian ASI Saja Pada Anak Usia o-11 Bulan. Tesis FKM UI.

Pope C, Mays N (2000). Qualitative Research in Health Care. London: BMJ Books.

Pudjiadi S (2001). Bayiku Sayang: Petunjuk Bergambar untuk Merawat Bayi dan Jawaban atas 62 Pertanyaan yang Mencemaskan. Jakarta: Fakultas Kedokteran UI.

Roesli U (2005). Mengenal ASI Eksklusif. Jakarta. Trubus Agriwidya.

Roesli U (2001). Bayi Sehat Berkat ASI Eksklusif. Jakarta: PT. Elex Media Komputindo.

Rohani (2010). Faktor-faktor Yang Meningkatkan Risiko Kegagalan Pemberian ASI Eksklusif pada Ibu Bayi Usia 6-9 Bulan di Kota Mataram Provinsi Nusa Tenggara Barat. Tesis. Universitas Udayana Bali.

Saleh LOA (2011). Faktor-faktor yang Menghambat Praktik ASI Eksklusif pada Bayi Usia o-6 Bulan. Tesis. Semarang: Program Pascasarjana Universitas Diponegoro.

Soetjiningsih (1997). ASI Petunjuk untuk Tenaga Kesehatan. Jakarta: Buku Kedokteran EGC.

(2007). Seri Gizi Klinik, ASI Petunjuk untuk Tenaga Kesehatan. Jakarta: Buku Kedokteran EGC.

Suhardjo (1992). Pemberian Makanan pada Bayi dan Anak. Yogyakarta: Kanisius.

Syah, Muhibbin (2008). PsikologiBelajar. Jakarta: PT. Raja Grafindo Press.

UNICEF (2010). Penuntun Hidup Sehat. UNICEF Indonesia.

UNICEF, WHO, IDAI (2005). Rekomendasi tentang Pemberian Makan Bayi pada Situasi Darurat: Jakarta.

Utomo B (2000). The Slowing Progress of Breastfeeding Promotion Program in 
Indonesia: Causes and Recommendation, Kumpulan Makalah Diskusi Pakar Bidang Gizi tentang ASI-MP ASI, Antropometri, BBLR, Kerjasama antara Persatuan Ahli Gizi Indonesia, LIPI, UNICEF.
Weimen J (2001).The Economic Benefits of Breastfeeding: A Review and Analysis, US Department of Agriculture, Food Assistance and Nutrition Research. Washington, DC.

Worthington BS (1993). Nutrition in Pregnancy and Lactation. USA. 